\title{
IDENTITAS KAUM SAMIN PASCA KOLONIA PERGULATAN NEGARA, AGAMA, DAN ADAT DALAM PRO-KONTRA PEMBANGUNAN PABRIK SEMEN DI SUKOLILO, PATI, JAWA TENGAH
}

\author{
Munawir Aziz \\ Sekolah Tinggi Agama Islam Mathali'ul Falah \\ Email: moena_aziz@yahoo.com
}

\begin{abstract}
Memmories of colonization have created an ethos of daily struggle among the followers of Saminism. Encounters with colonialism in the early 20 th century impacted Samins' character, ethos, and worldview, as demonstrated through their way of dealing with the Indonesian government, corporations, and other communities. This impact is evident in the case of the establishment of the Semen Gresik factory in Sukolilo, Pati, Central Java. The project plan of establishing a cement factory and exploration of Kendeng Mountain at Sukolilo created conflict among the people of Pati. The people were divided into two groups. The first supported the exploration and the second resisted. Samins, however, resisted it and stood against it for their environment. This article examines the Samins actions when dealing with outside powers, in this case the State and the cement corporation. It also studies how the Samins constructed their post-colonial worldview and identity in response to the state, religion, and capitalism. Using Gayatri sivak's theory of "subalternity", this article explains identity politics of the post-colonial Samin Movement.
\end{abstract}

Keywords: Samin, cement, identical a politics, pasca-colonial.

\begin{abstract}
ABSTRAK
Memori atas penjajahan memberi warisan etos perjuangan keseharian dalam diri kaum Samin. Perjumpaan dengan kolonialisme pada awal abad 20 berdampak pahatan memori pada watak, etos, dan world-view (pandangan dunia) kaum Samin ketika berhadapan dengan negara, perusahaan dan komunitas di luar dirinya. Hal ini tampak pada kasus pembangunan pabrik semen di Sukolilo, Pati, Jawa Tengah. Rencana pembangunan pabrik semen dan eksplorasi Pegunungan Kendeng di Kawasan Sukolilo, pati mengundang konflik di antara warga. Masyarakat di daerah Pati terbelah, antara mendukung atau menolak pembangunan pabrik semen. Namun, kaum Samin bersuara untuk mempertahankan lingkungan hidup. Artikel ini menggali aksi kaum Samin ketika berhadapan dengan kekuasaan, yang pada konteks ini tampak pada aparatur Negara dan perusahaan semen. Selain itu, proses kaum Samin untuk mengkonstruksi pandangan hidup dan identitasnya pada masa pascakolonial, khususnya ketika terjadi perbenturan dengan Negara, agama, dan kuasa ekonomi. Dengan menggunakan pisau analisis subalternity Gayatri Spivak, artikel ini berusaha menggali politik identitas dalam gerakan kaum Samin pascakolonial.
\end{abstract}

Kata kunci: Samin, semen, politik identitas, pasca-kolonial. 


\section{PENGANTAR}

Politik identitas kaum Samin pada masa kini dipengaruhi oleh pewarisan ingatan dan spirit perjuangan melawan rezim penjajah. Pada masa kolonialisme, di awal abad 20, kaum Samin melawan penguasa kolonial dengan keluguan dan 'ilmu bodon', yang masih tampak pada keturunan Samin generasi sekarang. Samin merupakan nama seorang priyayi-petani di Blora, Samin Surontika (Raden Kohar), yang menyebarkan pandangan hidup dengan menolak represi kolonial pada pergantian abad 19-20. Samin kemudian menjadi ideologi dan identitas gerakan bagi petani pada zaman kolonial, yang sampai saat ini masih ditemukan jejaknya. Pengikut Samin juga dianggap sebagai sedulur sikep, yang banyak tersebar di Blora, Pati, Kudus, Bojonegoro, Madiun dan beberapa kawasan sekitarnya (Koerver: 1976: 250). Pada masa kolonial, Samin Surontika (Raden Kohar) sebagai tokoh gerakan Samin menghimpun sebagian petani di desa-desa di Jawa Tengah dan Jawa Timur untuk melawan penjajah, dengan menolak membayar pajak, dan hal semacamnya yang berusaha menolak represi penguasa atas rakyat.

Selepas Indonesia merdeka, pada masa Orde Baru (1966-1998), kaum Samin dianggap sebagai anti-pembangunan, yang tak mau menerima bantuan dari pemerintah, serta tak dapat disentuh dalam proyek islamisasi maupun penginjilan. Kaum Samin juga menolak perangkat agama dan pemerintahan masuk dalam batas hidup komunitasnya. Pada masa pasca reformasi ini, warga Samin di Bombong, Baturejo, Sukolilo, Pati mengampanyekan penolakan pembangunan pabrik Semen karena dinilai merusak lingkungan. Warga Samin merasa bahwa pembangunan pabrik semen hanya menguntungkan segelintir orang, namun akan merusak lahan pertanian dan ekosistem pegunungan Kendeng, yang membujur di Pati selatan sampai Blora (Wawancara dengan Gunretno, Tokoh Muda Samin Sukolilo, 2011).

Artikel ini berusaha menggali politik identitas kaum Samin, ketika berhadapan dengan represi pemerintah dan oknumnya, perusahaan hingga instansi agama, pada masa pasca-kolonial, khususnya pada konteks pro-kontra pembangunan pabrik semen di Sukolilo, Pati, Jawa Tengah. Tulisan ini berusaha mengisi celah kosong terhadap hasil kajian dan literatur yang membahas tentang gerakan kaum Samin dan kehidupannya.

Beberapa penelitian terdahulu tentang gerakan Samin, dikerjakan oleh Harri J. Benda-Lance Castles (1969: 207-216). Dalam tulisannya, Harry J. Benda dan Lance Castles menjelaskan dengan baik tentang sebabsebab terjadinya gerakan yang dipimpin oleh Samin Surontiko, sebagai perlawanan petani melawan kolonial Belanda. Perlawanan ini dilakukan dengan cara menolak membayar pajak. Perlawanan yang dimulai di daerah Blora pada 4 Februari 1907 dalam waktu singkat mempunyai pengikut yang banyak, antara lain di: Rembang, Ngawi, Bojonegoro, Pati, Tuban, Grobogan dan Kudus.

Selain itu, Justus M. van der Kroef (1952: 161-165) menulis tentang perlawanan kaum Samin melawan kolonial Belanda dengan imajinasi sosok ratu Adil atau messiah dalam diri Samin Surosentika. Politik imajinasi ini memberi tekanan pada semangat perlawanan bahkan sampai saat ini. Victor T. King (1973: 457-481) dalam kajiannya membahas tentang gerakan kaum Samin di Jawa Tengah bagian utara untuk menganalisis perkembangan gerakan dengan fondasi ekonomi pada masyarakat bukan wilayah hutan. A. Pieter E. Korver (1976: 249-266) mengkaji Samin dalam kerangka gerakan millenarisme, sebagai identitas gerakan.

Takashi Shiraishi (1990: 95-120) melakukan review atas laporan kolonial terhadap warga pengikut Samin (Dangir) di Genengmulyo, Juwana untuk membaca pengaruh saminisme di beberapa daerah di pesisir utara Jawa. Bennedict Anderson (1996) dan Amrih Widodo (1997) lebih menekankan kajian pada kaum Samin pasca kemerdekaan, serta bagaimana pergulatan kuasa-adat yang terjadi, seperti tampak juga pada kajian tentang hak-hak minoritas yang dilakukan Uzair Ahmad (2007). 
Suripan Sadi Hutomo (1996) menulis tentang tradisi yang ada di Blora, sebagian membahas tentang kehidupan warga Samin di Klopoduwur, Blora. Suripan menggambarkan secara konkret hasil penelitian dan pengamatannya terhadap penerus Samin Surosentika yang masih ada di kampung asalnya, yaitu di Klopoduwur. Selain itu, Suripan juga membahas tentang pola ucap, pola komunikasi dan permainan simbol yang ada di kaum Samin, serta analisis terhadap teks-teks penting yang menjadi pedoman kearifan warga Samin.

Tim peneliti dari Fakultas Ilmu Sosial dan Ilmu Politik Universitas Muhammadiyah Malang (UMM) menulis sebuah buku berjudul Agama Tradisional Potret Kearifan Hidup Masyarakat Samin dan Tengger (Nuruddin dkk, 2003). Buku ini dibagi menjadi dua bagian yang pertama tentang masyarakat Samin dan kedua tentang masyarakat Tengger. Dalam bagian pertama (tentang masyarakat Samin) bahwa penelitian dilakukan di Desa Klopodhuwur, Kecamatan Banjarejo, Kabupaten Blora pada tahun 2003 menekankan tentang reaksi komunitas Samin terhadap modernisasi, yang tampak pada program-program pengembangan dari pemerintah.

Selain itu, Moh. Rosyid melakukan riset terhadap kehidupan kaum Samin di Undaan Kudus. Rosyid berpendapat bahwa, masyarakat Samin dapat bergaul ramah dengan warga di sekitar lokasi tempat tinggalnya, tetapi masih memegang nilainilai prinsip dasar yang menjadi warisan dari leluhur, seperti "agama Adam" dan pola komunikasi dengan anggota kelompok maupun di luar kelompok (Rosyid, 2008). Agama Adammerupakanmodelkepercayaan komunitas Samin yang menganggap bahwa nilai-nilai agama diwariskan dari ajaran Nabi Adam, Sang Manusia pertama. Ajaran "agama Adam" mengukuhkan persaudaraan sosial dan etika kemanusiaan, semisal tidak boleh berbohong, mencuri dan mengambil hak milik orang lain, meskipun ditemukan di jalan tanpa pemilik.
Dari beberapa naskah tentang gerakan Samin, sebagian besar berada pada domain historiografi, agama, budaya hingga politik penguasa atas komunitas adat. Penelitian ini berusaha mengisi celah kajian tentang kaum Samin dengan menggunakan kerangka postcolonial perspective, untuk menganalisis isu terbaru berupa kasus pro-kontra pembangunan pabrik semen di Sukolilo, yang melibatkan kaum Samin dalam kontestasi aspirasi.Denganmenggunakansudutpandang pasca-kolonial untuk membaca gerakan kaum Samin masa kini akan ditemukan benang merah dalam mengkonstruksi kesadaran politis, antara penyerbu dan penjajah masa kini, yang berubah: dari kepentingan kolonial menjadi politik penguasa lokal dan kepentingan ekonomi korporasi. Leela Gandhi mengungkapkan bahwa postcolonial membantu untuk menjernihkan pola perbedaan antara 'native dan invader', serta untuk mengkosntruksi kesadaran politik, menyatukan gerakan revolusioner, dan berdiri untuk melawan penjajah baru (Gandhi, 1998: 11).

\section{PEMBAHASAN \\ Samin dan Genealogi Gerakan}

Gerakan Samin pada awalnya merupakan gerakan petani yang menolak mengikuti perintah kolonial. Samin Surontika merupakan tokoh dari gerakan ini, yang kemudian melebar tak hanya di Blora, tetapi juga di beberapa kawasan lain. Samin Surontika, atau Surosentika, lahir di sekitar Blora. Nama kecilnya adalah Raden Kohar, beliau adalah seorang keturunan priyayi, yang memiliki beberapa lahan garapan yang cukup luas. Namun, memilih untuk menjadi petani dan menggerakkan perlawanan dari warga desa untuk melawan kekuasaan kolonial.

Pada tahun 1890, Samin mulai menyebarkan pengaruhnya di sekitar Bojonegoro dan Blora. Tahun 1905, Samin mulai menarik warga untuk mengikuti prinsipnya, menolak menyumbang untuk lumbung desa yang dikelola pemerintah kolonial, menolak menggembala ternak 
bersama-sama, dan menolak membayar pajak. Pada bulan Januari 1903, resident Rembang melaporkan bahwa ada sekitar 772 pengikut Samin di 34 desa di perbatasan Blora Selatan dan Bojonegoro. Surohidin dan Karsijah, menantu Samin, aktif dalam melakukan pengajaran bagi warga dan petani di sekitar tempat tinggalnya (Benda and Castles, 1969: 211). Dari pola inilah, pengikut Samin menyebar di beberapa daerah di Jawa Timur dan Jawa Tengah.

Perlawanan Samin Surontika beserta pengikutnya ini merupakan gerakan grassroot yang ditujukan untuk melawan represi kolonial, dan menyangkal kekuasaan negara sebagai alat eksploitasi pajak. Tidak hanya bertindak dalam perlawanan kelas petani dan penduduk desa, gerakan Samin juga menjadi idelogi. Penyebaran ideologi Samin menggunakan pengaruh Samin Surontika sebagai tokoh dari para petani, yang dianggap Ratu Adil, atau gerakan millenarisnime (de Tall, 1976: 250-253). Millenarisme merupakan gerakan rakyat yang menghendaki adanya juru penyelamat, dalam konteks rakyat Jawa sebagai "ratu adil".

Pengikut Samin yang tersebar di beberapa kawasan di Jawa Tengah dan Jawa Timur, umumnya petani yang hidup dari menggarap lahan sawah dan menggembala ternak. Kebijakan pajak oleh pemerintah kolonial dirasakan memberi beban berat, kemudian mereka berpaling kepada gerakan pembebasan rakyat dari kaum petani. Penyebaran pengikut Samin diikuti dengan penyebaran pengaruh dan ideologi, tidak hanya penolakan terhadap kewajiban membayar pajak, tetapi prinsip dalam mengelola sumber daya alam: lemah pada duwe, banyu pada duwe, kayu pada duwe yang berarti bahwa tanah, air dan kayu adalah milik bersama (Widiyanto, 1983: 64). Pengikut Samin juga memiliki logika dan cara pandang dunia yang berbeda dengan pandangan masyarakat umumnya, khususnya ketika berkaitan dengan represi penguasa, seperti yang tampak pada antara seorang patih dan pengikut Samin ini dalam kutipan ini.
+ "Kamu masih hutang 90 cent kepada negara"

- "Saya tidak meminjam apa pun kepada negara"

+ "Tapi kamu mesti bayar pajak"

- "Wong Sikep tidak mengenal pajak".

Logika pengikut Samin yang tampak pada dialog di atas sekilas tampak lugu, tetapi jika dicermati secara mendalam, akan muncul sebersit perlawanan dengan menggunakan logika bahasa. Atau pada dialog ini, antara seorang priyayi dan pengikut samin:

+ "apa kamu gila atau pura-pura gila?

- Saya tidak gila dan juga tidak pura-pura gila"

+ Kamu biasanya bayar pajak, kenapa sekarang tidak?

- Dulu itu dulu, sekarang itu sekarang. Kenapa negara tak habis-habis minta uang?

+ "Negara mengeluarkan uang juga untuk penduduk pribumi. Kalau negara tak punya cukup uang, tak mungkin memelihara jalan-jalan dengan baik.

- Kalau menurut kami keadaan jalanjalan itu mengganggu kami, kami akan membetulkannya sendiri.

+ Jadi kamu tak mau bayar pajak?

- Wong Sikep tak kenal pajak" (Widiyanto, 1983).

Dengan demikian, gerakan Samin merupakan perlawanan petani terhadap kekuasaan kolonial, dengan menggunakan strategi anti-kekerasan. Ada pembelokan 'logika bahasa', sebagai alat untuk menghindari represi. Takashi Shiraishi mengungkap bahwa wong sikep memiliki ciri-ciri seperti berikut:

Pertama, konsep utama agama Adam sebagai hidup (urip), yang merupakan inti dari bentuk kehidupan berupa suksma/ nyawa. Hidup (urip) punya banyak makna, namun semua bentuk dibagi menjadi dua: wong (orang) dan sandang pangan (pakaian dan makanan).

Kedua, semua aktivitas manusia dimaksudkan untuk dua hal: (1) tatane wong, mengelola hidup dengan melakukan sikep rabi (sexual intercouse). (2) toto nggaoto, memproduksi sandang pangan dengan 
mengelola lahan. Ringkasnya, lelaki ngitjir (menanam) dan perempuan nganakake (melahirkan).

Ketiga, wong, ada dua macam: wong Jowo, yang jujur, menepati janji, dan tidak melakukan kejahatan. Sedangkan wong Jawal, adalah gila dan jahat. Wong Sikep hidup dengan menghayati agama Adam dan menjadi wong Jawa dengan segala identitas moralnya (Shiraishi, 1990: 114).

Dalam agama Adam, pengikut Samin menganggap bahwa Adam sebagai lorong menuju spiritualitas (Agama iku gaman, gaman lanang, Adam pengucape). Maksudnya adalah agama merupakan alat untuk menjalin hubungan dengan Yang Maha Mencipta (Sing Nduwe Jagad), dan juga perisai untuk melindungi diri. Ajaran-ajaran Adam adalah ajaran moral kemanusiaan, yang diyakini pengikut Samin sebagai fondasi moral dan adat komunitasnya (Widodo, 1997).

\section{Dari Samin menuju Semen}

"Kahanane tumrap bangsa saiki, kaya endhog ing pucuk sungu, punika yen mleset niba akhire. Wong cilik ngantu-ngantu, tumalawung sakjroning ati. Mbokya isa mardika lahir batinipun. Jawa moga ndang baliya, manjing ing jiwa pribadi. Bali jiwa kang nyata ... "

Artinya: "Kondisi bangsa saat ini, seperti telur di puncak tanduk, jika meleset akan jatuhnya akhirnya. Orang kecil menantinanti, yang mendalam di dasar hati (jiwa). Semoga bisa merdeka lahir batin. Jawa semoga lekas kembali, masuk dalam jiwa tiap manusia. Kembali pada jiwa yang nyata." Ini merupakan tembang pembuka pada pertemuan warga Samin, Baturejo, Sukolilo, Pati, 25 Agustus 2005 (Hartono, 2005).

Pada tujuh tahun terakhir, warga Kabupaten Pati disibukkan oleh rencana proyek pembangunan Pabrik Semen di Sukolilo (Azis, 2009). Pemerintah Provinsi Jawa Tengah (Jateng) dan Pemerintah Daerah Kabupaten Pati, secara simbolis telah menjalin kesepakatan dengan PT Semen Gresik (SG), untuk membangun Pabrik Semen di daerah Sukolilo. Rencananya, Pabrik semen ini akan mengambil bahan tambang dari Pegunungan
Kendeng, serta lahan pertanian yang kaya tanah liat, sebagai bahan pembuatan semen. Pegunungan Kendeng, merupakan salah satu pegunungan yang berlimpah bahan karts, serta mineral-mineral lain.

Dalam tahapan awal proyeknya, PT Semen Gresik didukung Pemerintah Provinsi Jateng dan Pemda Pati, menggandeng Lembaga Penelitian Lingkungan dari Universitas Diponegoro (Undip) Semarang, untuk melakukan kajian Amdal (Analisis Mengenai Dampak Lingkungan) terkait eksplorasi bahan tambang dan kelayakan pembangunan pabrik Semen. Pihak Undip menyatakan bahwa Pegunungan Kendeng Sukolilo layak dijadikan sebagai lokasi tambang (www. undip.ac.id/download/chafid-amdal-SG. pdf), dan (http://suaramerdeka.com/v1/ index.php/read/cetak/2011/05/23/147313/ Sosialisasi-Amdal-Pabrik-Semen-Diprotes), diakses pada 13 Februari 2012).

Namun, keinginan Pemerintahan Provinsi Jateng dan Pemda Pati, yang mendukung PT Semen Gresik untuk mengeksplorasi Pegunungan Kendeng, tidak serta merta mendapat persetujuan dari masyarakat lokal, terutama warga Sukolilo, Kayen dan Tambakromo-tiga kecamatan terdekat dengan Pegunungan Kendeng. Beberapa kelompok masyarakat, LSM, dan ormas, bahkan menyatakan tidak setuju dengan rencana pembangunan pabrik semen sebab akan menghadirkan ancaman berupa kerusakan lingkungan. Meskipun Pemda Pati bersikeras menyampaikan kepada publik bahwa pembangunan pabrik semen di Sukolilo, akan sangat menguntungkan masyarakat Pati, pro-kontra meledak, melampaui lingkaran perdebatan antara menolak dan menerima: masyarakat Pati terbelah menjadi dua bagian (Wawancara dengan Abdul Hamid, tokoh pemuda Sukolilo, 4 Juni 2010).

Sebagian warga Sukolilo, Kayen, dan Tambakromo menolak pembangunan pabrik semen sebab dianggap hanya akan merusak lingkungan serta tidak menambah kesejahteraan warga lokal. Keuntungan hanya akan diambil oleh elit politik, maupun 
makelar tanah. Puluhan LSM, semisal Jaringan Masyarakat Peduli Pegunungan Kendeng (JMPPK), SHEEP Indonesia, Serikat Petani Pati (SPP), serta warga Samin, yaitu komunitas tradisional penerus ajaran Samin Surosentika, menolak pembangunan pabrik Semen, sebabdianggaphanya sebagaiperusak lingkungan (Wawancara dengan Husaini, aktifis Sheep Indonesia, Pati, 5 Juni 2010). Warga Samin sendiri bahkan mengadakan kajian khusus, dengan perangkat sederhana yang dirumuskan dari kearifan lokal, untuk mendata dan menganalisis potensi pegunungan Kendeng, serta membuat skema dasar tentang kerusakan lingkungan, jika pegunungan Kendeng dikeruk untuk kepentingan pembangunan pabrik semen.

Pro-kontra yang terjadi di sekitar pembangunan bahkan berlanjut tidak sekedar hanya persoalan menolak dan menerima, tetapi melampaui menjadi problem keagamaan dan relasi sosial. Pihak penolak pabrik semen, setia dengan prinsipnya menentang eksploitasi lingkungan, menyelenggarakan puluhan kali demonstrasi ke Pemda Pati maupun Pemprov Jawa Tengah. Gunretno, tokoh pemuda Samin, mengungkapkan bahwa warga Samin bukannya menentang pembangunan, tetapi menolak perusakan lingkungan yang diakibatkan oleh eksploitasi pabrik semen, seperti yang terjadi di Tuban. Gunretno mengisahkan:

"Kulo lan sak rencang rak sampun dolan menyang Tuban, ningali sedulur-sedulur ingkang manggon mriko, wonten lokasi pabrik Semen. Kulo lan sedulur puniko angresapi trenyuh, bilih urip sedulur wonton Tuban punika langkung ngenes, mboten sami kaleh janji pabrik semen.

(Saya dan sesama Sedulur Sikep - sebutan bagi pengikut Samin - sudah berkunjung ke Tuban, melihat saudara-saudara yang ada di sana, di dekat lokasi pabrik Semen. Saya dan sedulur merasa trenyuh/iba, tentang kehidupan saudara yang ada di Tuban yang menyedihkan, tidak sama dengan janji dari pihak Pabrik Semen)."
Gunretno merupakan salah satu tokoh penggerak warga Samin di Sukolilo, Dia merupakan cucu-menantu dari Mbah Tarno, salah satu sesepuh Samin Bombong, Sukolilo. Mbah Tarno meninggal (ganti sandangan) pada Juli 2009, pada usia 101 tahun. Selama hidupnya, Mbah Tarno teguh pada pendirian, dan merupakan tokoh kunci sedulur sikep di Sukolilo dan sekitarnya. Pada awal 2009, ketika penulis berkunjung, Mbah Tarno mengungkapkan bahwa, "Jawa Tengah kuwi wetenge Jawa, dadi ora keno diutak-atik, sebab ndadekno rusak kabeh neng tanah Jowo. (Jawa Tengah itu perutnya Jawa, jadi tidak boleh diutak-atik, sebab akan akan merusak semua di tanah Jawa). Pandangan Mbah Tarno ini bersumber dari etika lingkungan yang ia warisi dari sesepuhnya, Samin Surosentiko, yang menolak penindasan humanis dari pejabat kolonial belanda, pada awal 1900-an (Benda dan Castles dalam de Tall, 1969: 125).

Pro-kontra pembangunan pabrik Semen melintasi ruang sosial, ekonomi, budaya maupun agama di kalangan warga Sukolilo serta warga Pati secara umum. Elite Ormas di Pati, cenderung lebih banyak berada pada posisi moderat di tengah prokontra pembangunan pabrik semen, semisal Nahdlatul Ulama dan organisasi underbow dalam strukturnya. Pengurus Daerah Muhammadiyah mendukung pembangunan pabrik Semen. Begitu juga dengan beberapa aliran keagamaan, yang relatif lebih kecil, semisal Rifa'iyyah, dan Lembaga Dakwah Islam Indonesia (LDII).

Dalam struktur sosial-keagamaan warga Sukolilo, Islam merupakan agama terbesar: NU sebagai mayoritas, disusul Muhammadiyah, lalu Rifai'yyah, LDII, juga ada beberapa penganut Islam-kejawen. Selain itu, ada juga pengikut Kristen Katolik, Budha, dan Hindu. Warga keturunan Tionghoa juga bermukim di daerah ini, meski lebih banyak tinggal di kota Pati, untuk menjalankan bisnisnya. Di Sukolilo, warga Samin bermukim di Dukuh Bombong, Baturejo, Sukolilo, mencapai ratusan kepala keluarga. Ini merupakan jumlah terbesar dari kaum Samin pasca Samin Surosentika, yang 
bermigrasi dari Klopoduwur, Blora, menuju Bojonegoro, Tuban, Rembang, Purwodadi, Sukolilo (Pati), hingga Undaan (Kudus). Penelusuran yang dilakukan oleh penulis berdasar data teks dari buku-buku yang ada, maupun data lapangan. Komunitas Samin di Kudus tidak sampai seratus orang (Rosyid, 2008), sedangkan Samin Klopoduwur berjumlah 64 keluarga (Wawancara dan penelitian lapangan, Klopoduwur Blora, 4 Juni 2012).

Pada konteks keagamaan Sukolilo, ketika isu pro-kontra semen meningkat, warga Samin yang menolak rencana ekslorasi pegunungan Kendeng dianggap merupakan golongan kafir oleh sebagian elite agama di Sukolilo, yang belakangan diketahui mendukung pembangunan pabrik Semen, sebab telah menjalin komunikasi dengan PT SG. Di desa-desa sekitar Sukolilo, warga juga terpecah, pengajian dan sholat berjamaah pun menjadi terbelah, antara kelompok pendukung dan penolak pabrik Semen (Wawancara dengan KH. Asmui Syadzali, Rais Syuriah PC NU Pati, 02 Juni 2010).

Selain itu, pro-kontra juga berkembang menjadi konflik sosial di antara warga di Sukolilo. Kelompok pendukung pabrik Semen dianggap hanya mendapat uang upeti dan bayaran dari PT SG. Sebaliknya, penolak pabrik Semen SG dianggap hanya merupakan pendemo bayaran, yang dibiayai LSM maupun pabrik semen lain, semisal Holcim maupun Tiga Roda, yaitu kompetitor dari Semen Gresik (SG) (Wawancara dengan Pak Bambang, guru SMPN 01 Sukolilo, 4 Juni 2010, Abdul Hamid, pemuda dan aktifis Sukolilo, 4 Juni 2010, serta Husaini, direktur SHEEP bagian Pati, 28 Mei 2010).

Nuansa konflik berbasis ekonomipolitik, yang bergeser menjadi konflik keagamaan meluas di kehidupan warga Sukolilo. Aktivitas sosial-keagamaan menjadi tidak netral, dan sebagian fungsionaris organisasi kemasyarakatan merasakan dilema ketika akan menjalankan program sosial di daerah. Hubungan yang toleran antar agama, juga tidak lagi netral dan bernuansa politis. Elit ormas seperti NU maupun
Muhammadiyah terlibat dalam komunikasi maupun lobi politik dengan pemerintah maupun SG. Majelis Ulama Indonesia (MUI) Pati dianggap sudah tidak netral, sebab sejak awal terang-terangan mendukung PT SG. Sikap tokoh agama ini menyebabkan elemen warga yang menolak perusakan lingkungan yang terjadi bila pabrik semen dibangun menyatakan sangat kecewa dengan elit agama (Wawancara dengan Gunarti, warga Samin, 4 Juni 2010; Herusansono, "Masalah Pabrik Semen, Pemerintah Harus Pertimbangkan Sosio Kultural," Kompas, 31 Januari 2009 dari http:// lipsus.kompas.com/grammyawards / $\mathrm{read} / 2009 / 01 / 31 / 11444222 /$ Masalah. Pabrik.Semen..Pemerintah. Harus. Pertimbangkan.Sosio.Kultural, diakses pada 14 April 2012).

\section{Samin, Represi, dan Subalternitas}

Pada konteksini, wargaSamin diSukolilo dianggap sebagai kelompok yang menolak pembangunan, tidak waras, tidak agamis, tidak bertuhan, hingga penyebab kekafiran bagi warga sekitar. Selain itu, muncul stigma negatif terhadap masyarakat Pati daerah selatan yang menolak pembangunan semen, dengan dinyatakan sebagai kelompok komunis, marhaen, dan pemberontak. Citra ini kemudian menimbulkan depresi sebagian warga, hingga ada yang mengalami tekanan mental (Yumni, 2012).

Kaum Samin yang terbungkam dan dipinggirkan dalam peta komunikasi massa, masuk dalam ranah "subaltern", meminjam teori Gayatri Spivak. Menurut Spivak, subaltern lahir dari peminggiran politik oleh kekuasaan yang diteruskan dengan pelanggengan marginalisasi budaya, ekonomi, dan agama. Subyek dalam konsep subalternity, bergerak di level elit politik dengan membajak kekuasaan, dan kaum marginal dinarasikan dalam ruang sejarah dan panggung kebudayaan yang melintasi dimensi-dimensi lain. Spivak mengungkapkan: the subject implied by the text of insurgency can only serve as a counterpossibility for the narrative sanctions granted to the colonial 
subject in the dominant groups (Spivak, 1995: 27-8).

Menurut Spivak bahwa asumsi yang melatarbelakangi analisisnya terhadap komunitas subaltern dan gerakan pendampingan yang digerakkannnya dalam sebuah lingkungan kecil yang berefek pada struktur politik; in the context of colonial production, the subaltern has no history and cannot speak (Spivak, 1995: 28). Narasi sejarah pascakolonial didominasi oleh elit kekuasaan dan tak memungkinkan kaum marginal menarasikan dirinya.

Selain itu, dengan mengandaikan kaum Samin sebagai subaltern community, maka dapat digali secara mendalam memori kolektif dan relasinya dengan kekuasaan, sebagai bagian dari pembacaan atas determinasi politik dalam kontinuitas sejarah komunitas yang berlabel "indigenous community". Spivak menulis bahwa subaltern studies menjadi instrumen untuk melihat masyarakat subaltern berada pada wilayah yang terpinggirkan, di mana sejarah kaum subaltern lahir dari kuasa elite (Spivak in Aschroft, 1995: 27). Pada titik ini, kaum subaltern menurut Sumit Sarkar berusaha untuk menghindari perangkap reduksi ekonomi, pada waktu yang sama, mempertahankan dorongan untuk menolak eksploitasi, dan dominasi (Sarkar dalam Chateurvedi, 2000: 301).

Jika pada awal perpindahan abad 19 dan 20, kaum Samin berhadapan dengan kuasa kolonial. Pada abad 21 ini, kaum Samin dipinggirkan oleh pejabat negara dan kepentingan korporasi yang ingin mengeksploitasi lahan. Ketika berhadapan dengan penguasa kolonial, warga Samin melawan dengan menolak membayar pajak dan gerakan lain untuk membantu kaum petani bebas dari cengkeraman kolonial. Pada masa kini, ketika berhadapan dengan kehendak kuasa oknum pemerintah dan kepentingan perusahaan, kaum Samin melawan dengan menolak eskploitasi pegunungan Kendeng. Ekspresi penolakan dan identitas kaum Samin, tampak pada pola gerakan sebagai berikut:

\section{Penolakan terhadap Eksploitasi Lahan}

Gerakan Samin dalam menolak penjajahan masa sekarangyang berupa politik transaksi penguasa dan kepentingan ekonomi korporasi, tampak pada penolakan terhadap rencana pembangunan pabrik Semen di pegunungan Kendeng. Pembangunan pabrik semen ini akan mengekploitasi material pegunungan Kendeng, yang selama ini menjadisumberairdan cagar alam di kawasan Sukolilo. Kaum Samin menganggap bahwa pegunungan Kendeng adalah 'paku bumi' bagi keseimbangan ekosistem Jawa (Azis, 2009). Perusakan terhadap pegunungan Kendeng, bagi kaum Samin merupakan awal perusakan tanah Jawa secara umum. Mbah Tarno, sesepuh Samin Baturejo, menyatakan sebagai berikut:

Yo ngeniku mau, dadi buyut ki amung tani buyute wong sak nuswantoro kabeh, seng kepengen nglelo, piye.. Yen kepengen nandur, nandur dalane mangan nyandang. Ki cawisane anak putu buyut, canggah, wareng, udek-udek.

Ki seng diudek malah peraturane, iki bagiane anak putu ngasi udek-udek gandrung siwur, emboh ki nenek moyang ki pesene ngono., yo tak kandakno opo anane.. Dene yo nandur monggo, nek ora yo sak kerso... (Wawancara dengan Mbah Tarno, 2009).

(ya itu tadi, jadi nenek moyang itu bercocok tanam, yang menjadi nenek moyangnya orang se-nusantara. Yang ingin mengelola lahan.. yang ingin menanam, tanam sumber pangan-sandang. Ini bagiannya anak cucu, canggah, wareng, udek2 [keturunan]. Namun, sekarang ini yang dimainkan itu malah peraturannya, ini bagian anak cucu sampai keturunan jauh, entah ini, nenek moyang pesennya ya begitu [untuk menjaga lahan dan keseimbangan alam], ya saya bicarakan apa adanya. Jika mau menanam ya silakan, kalau tidak ya terserah.. )

Penolakan kaum Samin terhadap rencana eksplorasi semen di kawasan pegunungan Kendeng merupakan salah satu ekspresi dari sikap hidupnya untuk menghargai keseimbangan alam (Pegunungan Kendeng yang membujur dari Pati sampai Blora menyimpan jutaan kubik karts dan material 
tambang lain. Mineral yang terkandung di pegunungan Kendeng berfungsi untuk menyimpan air, resapan air hujan dan rumah bagiflora-fauna.Perusakanolehtambangliardi beberapa titik kawasan pegunungan Kendeng menyebabkan banjir bandang di Sukolilo dan Kayen, Pati, pada 3 Desember 2011. Banjir ini menewaskan beberapa penduduk, merusak ratusan rumah, membunuh ternak dan menghancurkan lahan pertanian. Kompas, 4 Desember 2011, http://regional.kompas. com/read/2011/12/04/11162557/Dua. Tewas.Akibat.Banjir.Bandang.di.Pati, akses pada 14 April 2012).

\section{Politik Ingatan Nenek Moyang}

Bagi kaum Samin, gerakan perlawanan terhadap penjajah Belanda pada awal abad 20 mewariskan ingatan, etos, dan identitas. Nama Samin Surontika dikenang sebagai nenek moyang yang diteladani sikap dan cara berpikirnya. Hampir di setiap rumah warga Samin di Bombong, Sukolilo dan Kaliyoso, Undaan, dan Kudus tergantung foto Samin Surosentika. Mbah Tarno, menyebutkan bahwa Samin Surosentika tak hanya sebagai nenek moyang, juga simbol identitas wong Sikep:

Lha yo, kuwi ra aran-aran tho. Samin kuwi pengaran wong.. kuwi gambare nek gedheg. Mbah Surontiko, pengarane cilik kuwi Raden Kohar.. nek gedhe ditambahi wong tuwane, Surosentiko Samin. Jaman belanda kuwi, diatur belanda ki emoh.. Mulane koyo aku barang kuwi, jaman kae yo ngono, Mergo tanah iki yo tanahtanah ne yo dewe, londo ra nduwe neng kene, nyatane Londo disingkap Jepang, bali ra nggowo ndah-ndeh.

Mengko wong jowo kuwi nggek-nggeke dewe.. Manuke ko lambang. Manuk ki ono keneng ngakngkuk.. mengko wong Jowo iso dingkak-ngkuk. Penjajah belanda jaman kono.. Tanah-tanah dewe dadi, Padahal sipatan seng jejek, mulane jo nyembah nyeleweng wae.. mulane $i k u$ jowo podo jowo, Karepe kuwi ngono.. Jowo podo jowo, yo unen2 mbangun (Wawancara Mbah Tarno, 5 April 2009)

"lha iya, itu akan nama. Samin itu nama orang. Itu ada gambarnya di dinding. Mbah Surontika, nama kecilnya Raden
Kohar. Kalau besar ditambah orang tuanya, Surosentika Samin. Pada zaman Belanda, diatur Belanda itu ndak mau. Makanya, seperti saya ini, zaman itu ya seperti itu, sebab tanah ini kan tanah milik sendiri. Belanda tidak punya di sini. Kenyataanya, Belanda digempur Jepang, pulang tidak bawa apa-apa."

(Maka, orang Jawa itu miliknya sendiri. Burungnya itu jadi lambang. Burung (manuk) itu bisa di ngkak-ngkuk, bisa dibentuk-bentuk. Maka, orang Jawa itu bisa dibentak-bentuk, ditindas oleh penjajah Belanda zaman itu. Tanah milik sendiri, padahal harus punya sifat teguh, makanya jangan menyeleweng [dari prinsip], Makanya itu sesama orang Jawa, seharusnya seperti itu. Jawa dengan Jawa, ya semestinya saling membangun/membantu).

Ungkapan Mbah Tarno ini seakan memberi landasan memori bagi gerakan perlawanan kaum Samin terhadap represi penguasa, dari zaman kolonial sampai kemerdekaan yang diwakili oleh oknum pemerintah dan pengusaha. Penggunaan nama Samin Surosentika sebagai nenek moyang merupakan 'politik ingatan' untuk melegitimasi gerakan perlawanan dan juga sebagai usaha menawarkan 'kebenaran sejarah' dari pada 'klaim sejarah' (Budiawan, "Bung Karno sebagai (Nara)Sumber Pelajaran Sejarah" http://www.kompas.co.id/ kompas-cetak/0603/12/Buku/2501555. htm) Mbah Tarno, sebagai sesepuh Samin di Sukolilo bermaksud untuk mewarisi spirit perjuangan Samin Surosentika kepada sedulur Sikep. Gerakan perlawanan nenek moyang Samin pada awal abad 20 merupakan legitimasi gerakan penolakan eksploitasi semen, bertujuan menjaga sumber penghidupan dan kelestarian alam.

Politik ingatan, bagi Homi K. Bhabha tidak hanya bermaksud sebagai usaha reflektif dan historiografis. Ia menyatakan: remembering is never a quiet act of introspection or retrospection. It is a painful re-membering, a putting together of the dismembered past to make sense of the trauma of the present (Bhabha, 1994: 63). Politik ingatan sedulur Sikep tentang 
gerakan perlawanan nenek moyangnya tak sekedar nostalgia, namun menjadi gerakan dalam masa pasca-kolonial. Mengenai hal ini, Leela Gandhi mengungkap bahwa mengingat dan melupakan merupakan strategi bagi kaum terjajah. Melupakan dan menghapus kenangan penjajahan merupakan usaha untuk memulai gerakan emansipasi yang baru, di era pasca-kolonial.

Postcolonial amnesia is symptomatic of the urge for historical self-invention or the need to make a new start to erase painful memories of colonial subordination. As it happens, histories, much as families, cannot be freely chosen by a simple act of will, and newly emergent postcolonial nationStates are often deluded and unsuccessful in their attempt to disown the burdens of their colonial inheritance (Gandhi, 1998: 4).

Akan tetapi, pada Sedulur Sikep mengingat-melupakan merupakan proses politik untuk mewariskan semangat perjuangan, seperti yang tampak pada gerakan penolakan eksploitasi material di pengunungan Kendeng. Bahasa menjadi bagian penting dari strategi politik komunikasi dan politik ingatan kaum Samin (Widodo, 2000: 19).

\section{Pondok Pasinaon}

Perlawanan terhadap perangkat negara masih tampak pada penolakan untuk sekolah secara formal. Namun, bukan berarti sedulur sikep bodoh dan tidak mengerti perkembangan informasi. Mereka tetap belajar secara berkelompok yang berbasis rumah, yang mereka sebut sebagai 'pondok pasinaon' (Rosyid, 2008). Pondok pasinaon ini merupakan semacam sistem dan perangkat budaya bagi warga Sedulur sikep untuk mengajar generasi muda tentang ilmu baca-tulis, menghitung, moral, dan cara menggarap lahan. Di rumah, pada orang tua warga Samin mengajar anaknya dengan prinsip-prinsip moral dalam keseharian. Ilmu baca tulis, menghitung dan nembang (bernyanyi), diajarkan secara komunal di sebuah balai di tengah pemukiman. Di Bombong, Baturejo terdapat sebuah balai untuk pengajaran anak-anak dan pertemuan warga Sedulur Sikep, begitu juga di daerah Kaliyoso, dan Kudus (Wawancara dengan Gunarti, perempuan sedulur sikep dan penggerak pondok pasionaon, 6 April 2009). Pondok pasionaon ini menjadi media untuk mewariskan etika dan nilai-nilai hidup sedulur sikep kepada generasi penerusnya. Lewat tembang dan dolanan, sikap sedulur sikep terhadap eksploitasi alam ditransformasikan pada anak-anak mereka.

\section{SIMPULAN}

Gerakan perlawanan kaum Samin pada awal abad 20 dan abad 21 menampilkan pola yang hampir sama. Jika pada masa kemunculannya, gerakan ini dikampanyekan oleh Samin Surosentika dan pengikutnya untuk melawan rezim kolonial Belanda dengan menolak membayar pajak, dan melawan represi penjajah. Pada masa sekarang, kaum Samin melawan 'penjajahan' dalam bentuk ekploitasi mineral di kawasan pegunungan Kendeng oleh oknum pemerintahan dan elit pengusaha. Gerakan perlawanan kaum Samin dalam rencana pembangunan pabrik Semen di Sukolilo, Pati, membawa konsekuensi berupa diskriminasi dan marginalisasi dalam ranah politik dan agama. Pada ranah politik, terjadi diskriminasi wacana dan stigmatisasi untuk meminggirkan sedulur sikep dan warga penentang pembangunan pabrik semen. Pada wilayah agama, stigma kafir sering diucapkan oleh pendakwah yang tidak memahami jalur berpikir warga sikep dan warga Sukolilo yang menolak eksploitasi lingkungan untuk material semen. Warga sedulur sikep dianggap sebagai pembangkang yang menolak pembangunan, bahkan dianggap kafir oleh sekelompok pemuka agama.

Akan tetapi, pada ruang kontestasi tersebut, prinsip hidup yang diwariskan dari gerakan perlawanan nenek moyang membentuk worldview dan identitas sedulur sikep. Gerakan kaum Samin pada masa pascakolonial tidak hanya reaktif, tetapi juga aktif 'menyuarakan' aspirasinya dengan ekspresi kultural, yaitu (1) keteguhan sikap menolak 
eksploitasi alam; (2), perlawanan terhadap represi kekuasaan dengan politik ingatan untuk membentuk kesatuan komunal; dan (3) transformasi pengetahuan dan kebudayaan melalui sistem 'pondok pasinaon'. Dari pondok pasionaon inilah, nilai-nilai moral dan etika sedulur sikep diwariskan kepada generasi mudanya, termasuk sikap terhadap eksploitasi lingkungan.

Gerakan sedulur sikep sebagai komunitas subaltern (subaltern community) pada masa pasca-kolonial tak hanya bungkam dalam represi penguasa, tetapi juga bersuara. Setidaknya, kaum Samin dalam gerakannya menjawab lontaran Gayatri Spivak: Can the Subaltern Speak? Dengan aksinya, kaum Samin telah bersuara.

\section{DAFTAR PUSTAKA}

Anderson, B., 1996, Gerakan Millenarialisme dan Saminis" (Millenatialism movement and Saminism) in Benedict Anderson (ed), Agama dan Etos Sosial di Indonesia, Bandung: AlMa'arif.

Aziz, M., 2009a, Wacana Tanding Kaum Samin, Jakarta: Media Indonesia. , 2009b, Omah Kendeng kaum Samin, Jakarta: Kompas.

, 2008, Samin, Semen dan Konflik Kepentingan, Jakarta: Kompas.

Budiawan, "Bung Karno sebagai (Nara) Sumber Pelajaran Sejarah." Kompas. http:// www.kompas.co.id/kompascetak/0603/12/Buku/2501555.htm

Bhaba, H. K., 1994, The Location of Culture. London: Routledge.

Chaturvedy, V., 2000, Mapping Subaltern Studies and the Postcolonial, London: Verso.

Gandhi, L., 1998, Postcolonial Theory: a Critical Introduction. Australia: Allen\&Unwin.

Hartono, A. W., 2005, “Hidup Merdeka Warga "Sikep"; Berkat Sikap "Teges" dan Tak "Ita-itu," Suara Merdeka, 27 Agustus 2005.
2005, Hidup Merdeka Warga "Sikep"; Menjadikan Kejujuran sebagai "Saka Guru." 28 Agustus 2005.

Hutomo, S. S., 1996, Tradisi Dari Blora, Semarang: Citra Almamater.

King, V.T., 1973, Some Observations on the Samin Movement of the North-Central Java. BKI. Deel 129, 4e avlevering, 's-Gravenhage, Martinus Nijhoff.

, 1977, Status, Economic Determinism and Monocausality: More on the Samin. In Bijdragen tot de Taal, Land- en Volkenkunde, Deel 133, 2de/3de Afl.

Korver, A. 1976, The Samin Movement and Millenarism, in Bijdragen tot de Taal, Land- en Volkenkunde, 132 (1976), no: 2/3, Leiden, 249-266

Kroef, J. M., 1952, “The Messiah in Indonesia and Melanesia." The Scientific Monthly, Vol. 75, No. 3 (Sep., 1952)

Nuruddin, dkk., (editor), 2003, Agama Tradisional Potret Kearifan Hidup Masyarakat Samin dan Tengger, Yogyakarta: LkiS.

Rosyid, M., 2008, Samin Kudus: Bersahaja di Tengah Asketisme Lokal, Jogjakarta, Pustaka Pelajar.

Shiraishi, T., 1990, Dangir's Testimony: Saminism Reconsidered. Source: Indonesia, Vol. 50, 25th Anniversary Edition (Oct., 1990).

Spivak, G. C., 1995, "Can the Subaltern Speak?" In Bill Aschrof, The Postcolonial Studies Reader, London: Routledge.

Uzair, A., 2007, Politik Representasi dan Wacana Multikulturalisme dalam Praktik Program Komunitas Adat Terpencil (KAT) Kasus Komunitas Sedulur Sikep Bombong-Bacem. In "Hak Minoritas Dilema Multikulturalisme di Indonesia". Jakarta: Yayasan Tifa.

Van der Kroef, Justus M, 1952, The Messiah in Indonesia and Melanesia. The Scientific Monthly, Vol. 75, No. 3. 
Widodo, A., 1997, "Samin in the New Order: The Politics of Encounter and Isolation." In Jim Schiller and Barbara Martin Schiller (eds). Imagining Indonesia: Cultural Politics and Political Culture, Ohio: Ohio University Press. , 2000, “Untuk Hidup, Tradisi Harus Mati". Basis, September-Oktober, 2000.

Suara Merdeka, 2010, “Tradisi Pernikahan Sedulur Sikep: Pasangan Hidup Samin Tak Ada yang Bercerai." Semarang: Suara Merdeka. 06 April 2010.
Website:

http:/ / kompas.com

$h t t p / /$ undip.ac.id

http://suaramerdeka.com

\section{Wawancara:}

Mbah Tarno (5 April 2009)

Gunretno (5 April 2009)

Gunarti (6 April 2009, 4 Juni 2010)

KH Asmui Syadzali (2 Juni 2010)

Abdul Hamid (4 Juni 2010)

Pak Bambang (4 Juni 2010)

Husaini (28 Mei 2010) 